BAHTERA INDONESIA:

Jurnal Penelitian Pendidikan Bahasa dan Sastra Indonesia
ISSN 2541-3252

Vol. 5, No. 1, Mar. 2020

\title{
TRANSFORMASI TOKOH BISMA \\ DALAM CERPEN "PEREMPUAN YANG INGIN MEMBUNUH BISMA" KARYA GANUG NUGROHO ADI
}

\author{
Agus Nasihin \\ Program Studi Pendidikan Bahasa dan Sastra Indonesia \\ Universitas Wiralodra
}

Surel: agusnash@gmail.com

\begin{abstract}
ABSTRAK
Transformasi dalam bentuk karya sastra modern merupakan salah satu upaya pelestarian, pemertahanan eksistensi, dan penafsiran kembali konsep, nilai, dan norma-norma lama secara kontekstual. Dengan demikian, perlu adanya contoh analisis terhadap karya sastra yang berlatar belakang transformasi. Penelitian ini merupakan salah satu contoh analisis terhadap cerpen "Perempuan yang Ingin Membunuh Bisma" karya Ganug Nugroho Adi. Penelitian terhadap cerpen ini dimaksudkan untuk mengetahui bentuk transformasinya. Metode yang digunakan dalam penelitian ini adalah metode deskriptif-analitis. Teknik penelitian yang dilakukan untuk mendukung metode deskriptif ini, yaitu studi dokumentasi dan analisis data. Data penelitian ini adalah cerpen berbahasa Indonesia yang berjudul "Perempuan yang Ingin Membunuh Bisma" karya Ganug Nugroho Adi diambil dari Surat Kabar Harian Suara Merdeka tanggal 12 November 2007 Berdasar pada kisah pewayangan Bisma, transformasi secara utuh terjadi pada alur cerpen "Perempuan yang Ingin Membunuh Bisma". Tidak ada alur peristiwa yang menyimpang dari hipogramnya. Demikian pula dengan nama-nama tokoh yang muncul dalam cerpen ini sama persis dengan nama-nama dalam kisah pewayangan tentang kehidupan Bisma. Yang membedakan cerpen "Perempuan yang Ingin Membunuh Bisma" dengan hipogramnya adalah penguatan pada unsur tema dan pemuatan nilai-nilai ideologis feminisme.
\end{abstract}

Kata kunci: transformasi, hipogram, cerita pendek

DOI: https://doi.org/10.31943/bi.v5i1.64

Nasihin, A. (2020). TRANSFORMASI TOKOH BISMA DALAM CERPEN "PEREMPUAN YANG INGIN MEMBUNUH BISMA" KARYA GANUG NUGROHO ADI . Bahtera Indonesia; Jurnal Penelitian Bahasa Dan Sastra Indonesia , 5(1), 49-60. https://doi.org/10.31943/bi.v5i1.64 


\section{PENDAHULUAN}

Teeuw (1993:65) menyatakan bahwa sastra tidak lahir dalam kekosongan budaya. Suatu karya sastra merupakan respon terhadap karya sastra yang terbit sebelumnya. Oleh karena itu, sebuah teks tidak dapat dilepaskan dari teks lain. Sebuah karya sastra baru mendapatkan makna yang lengkap apabila dikontraskan dengan karya sebelumnya. Teks dalam pengertian umum adalah dunia semesta ini, bukan hanya teks tertulis atau teks lisan. Adat istiadat, kebudayaan, film, drama secara umum adalah teks. Oleh karena itu, karya sastra tidak dapat lepas dari hal-hal yang menjadi latar penciptaan tersebut, baik secara umum maupun secara khusus.

\section{Kristeva (Culler, 1977:} mengemukakan bahwa setiap teks merupakan mozaik kutipan-kutipan dan merupakan penyerapan (transformasi) teks-teks lain. Tiaptiap teks mengambil hal-hal tertentu, kemudian diolah kembali dalam karyanya atau ditulis setelah melihat, meresapi, menyerap hal yang menarik baik secara sadar maupun tidak sadar. Setelah menangapi teks lain dan menyerap konvensi sastra, konsep estetik, atau pikiranpikirannya kemudian mentransformasikan ke dalam karya sendiri dengan gagasan dan konsep estetik sendiri sehingga terjadi perpaduan baru. Konvensi dan gagasan yang diserap itu dapat dikenali apabila kita membandingkan teks yang menjadi hipogramnya dengan teks baru itu. Sebuah teks kesastraan yang dihasilkan dengan kerja yang demikian dipandang sebagai karya yang baru. Pengarang dengan kekuatan imajinasinya, wawasan estetika, dan horison harapannya sendiri telah mengolah dan mentransformasikan karya-karya lain ke dalam karya sendiri. Namun, unsur-unsur tertentu dari karya-karya tersebut, yang mungkin berupa konvensi-konvensi, bentuk-bentuk formal tertentu, gagasan, masih dapat dikenali. Usaha pengidentifikasian hal-hal itu dapat dilakukan dengan membandingkan antara teks-teks tersebut.

Karya-karya sastra Indonesia telah sejak lama menunjukkan adanya intertekstualitas dengan teks-teks sastra daerah. Munculnya karyakarya sastra Indonesia yang memiliki basis teks sastra lokal merupakan keniscayaan mengingat wilayah Indonesia yang terdiri atas ratusan bahasa dan budaya. Cerita-cerita daerah itu telah tertanam sejak kecil dalam kehidupan para penulis. Selain berlandaskan pada cerita-cerita rakyat, karyakarya sastra juga banyak yang mengambil latar cerita pewayangan. Menurut Nurgiyantoro (1998: 3) munculnya unsur cerita wayang dan bentukbentuk transformasinya pada karya fiksi Indonesia secara intensif baru terlihat pada pertengahan tahun 70-an. Latar belakang penulis yang menyerap unsur-unsur pewayangan ini banyak berasal dari etnis Jawa, seperti Umar Kayam, Mangunwijaya, dan Arswendo Atmowiloto.

Banyaknya pengarang yang mengangkat latar cerita pewayangan merupakan hal yang wajar karena cerita-cerita pewayangan mengangkat berbagai peristiwa dengan tokohtokohnya yang merepresentasikan watak manusia yang kompleks dan lengkap. Tokoh-tokoh wayang sering dijadikan sebagai simbol yang merepresentasikan seseorang di dunia nyata 
sebagai bentuk sindiran atau anutan. Cerita-cerita pewayangan bagi para penulis tersebut telah tertanam sejak usia kanak-kanak. Cerita-cerita pewayangan yang berasal dari India tersebut telah disesuaikan dengan falsafah Jawa atau ajaranajaran lokal dan ajaran-ajaran agama.

Karya sastra Indonesia modern yang berlatar sastra lokal dapat berupa respons, reaksi, bahkan penolakan atau penyimpangan terhadap sastra daerah yang merupakan teks dasar atau hipogramnya. Karya sastra Indonesia modern yang menggunakan latar belakang, teks dasar, atau hipogram dari karya sastra Nusantara dapat dikaji dengan menggunakan pendekatan intertekstual sehingga kita dapat mengetahui, apakah cerita rakyat nusantara yang dijadikan teks dasarnya itu mendapatkan modifikasi, ekspansi, ekserp, atau konversi (Riffaterre, 1980).

Pada zaman sekarang pertunjukan wayang sudah mulai jarang ditampilkan. Anakanak muda sekarang tidak banyak mengenal tokoh-tokoh wayang dan cerita-ceritanya. Oleh karena itu, transformasi dalam bentuk karya sastra modern merupakan salah satu upaya pelestarian, pemertahanan eksistensi, dan penafsiran kembali konsep, nilai, dan norma-norma lama secara kontekstual. Akan tetapi, karya sastra yang demikian akan menjadi kendala dalam pembelajarannya di sekolah apabila guru tidak menggunakan pendekatan dan model yang tepat. Dalam mengapresiasi karya sastra hasil transformasi dapat membuat peserta didik kebingungan karena karya sastra yang dihadapinya jauh dari cakrawala harapan (horizon of expectation) yang ada di benaknya. Gurulah yang dapat menyajikan dengan bijaksana jika guru sendiri memiliki wawasan mengenai latar belakang cerita dan tokoh-tokoh pewayangan serta cara mendekati dan menganalisis karya sastra hasil transformasi tersebut.

Berdasar latar belakang di atas, perlu adanya contoh analisis terhadap karya sastra yang berlatar belakang transformasi. Salah satu contoh analisis dalam tulisan ini adalah analisis terhadap cerpen berbahasa Indonesia yang berjudul "Perempuan yang Ingin Membunuh Bisma" karya Ganug Nugroho Adi. Penelitian terhadap cerpen ini dimaksudkan untuk mengetahui bentuk transformasinya.

Dari latar belakang masalah di atas dapat dirumuskan masalah sebagai berikut.

1. Unsur apa saja yang ditransformasikan dari cerita tokoh Bisma dalam cerpen "Perempuan yang Ingin Membunuh Bisma" karya Ganug Nugroho Adi?

2. Nilai-nilai apa saja yang terdapat dalam cerpen "Perempuan yang Ingin Membunuh Bisma" karya Ganug Nugroho Adi berkaitan dengan transformasi dari hipogramnya?

\section{KAJIAN TEORI}

\section{Struktur Cerita Pendek}

Cerita pendek atau sering disingkat sebagai cerpen adalah suatu bentuk prosa naratif fiktif. Cerita pendek cenderung padat dan 
langsung pada tujuannya dibandingkan karyakarya fiksi yang lebih panjang, seperti novella (dalam pengertian modern) dan novel. Karena singkatnya, cerita-cerita pendek yang sukses mengandalkan teknik-teknik sastra seperti tokoh, plot, tema, bahasa dan insight secara lebih luas dibandingkan dengan fiksi yang lebih panjang. Ceritanya bisa dalam berbagai jenis. Cerita pendek cenderung kurang kompleks dibandingkan dengan novel. Cerita pendek biasanya memusatkan perhatian pada satu kejadian, mempunyai satu plot, seting yang tunggal, jumlah tokoh yang terbatas, mencakup jangka waktu yang singkat. Berikut adalah struktur yang membangun sebuah cerita pendek.

\section{Penokohan}

Penokohan atau karakterisasi merupakan usaha untuk membedakan tokoh satu dengan tokoh yang lain. Karakterisasi atau perwatakan dalam sebuah cerita memegang peran yang sangat penting. Tanpa perwatakan tidak akan ada cerita. Dalam menganalisis karakter sangat penting untuk melihat empat tingkatan, yaitu (1) tingkatan fisik - seperti jenis kelamin, usia, ukuran, dan warna kulit; (2) tingkatan sosial - seperti status ekonomi, profesi atau keterampilan, agama, hubungan keluarga; (3) tingkatan psikologis seperti reaksi kebiasaan, sikap, keinginan, motivasi, hal yang disenangi dan yang tidak disenangi; (4) tingkatan moral.

\section{Alur}

Alur menurut Sudjiman (1984) adalah jalinan peristiwa di dalam karya sastra (termasuk naskah drama atau lakon) untuk mencapai efek- efek tertentu. Tautannya dapat diwujudkan oleh hubungan temporal (waktu) dan oleh hubungan kausal (sebab-akibat). Alur adalah kontruksi atau pola dari peristiwa-peristiwa dalam lakon yang menyebabkan pembaca atau penonton tegang dan ingin tahu. Secara umum pembagian alur terkadang menggunakan tipe sebab akibat yang dibagi dalam lima pembagian, yaitu eksposisi, aksi, krisis, klimaks, dan resolusi. Sedangkan jenis alur secara sederhana dapat dibagi menjadi dua, yaitu sederhana (alur linear dan linearcircular) dan alur kompleks (alur episode dan alur terpusat)

\section{Latar}

Pertanyaan untuk latar cerita adalah kapan dan di mana persitiwa terjadi. Pertanyaan tidak serta merta dijawab secara global tetapi harus lebih mendetil untuk mengetahui secara pasti waktu dan tempat kejadiannya. Analisis latar merupakan suatu usaha untuk menjawab sebuah pertanyaan apakah peristiwa terjadi di luar ruang atau di dalam ruang? Apakah terjadi pada waktu malam, pagi hari, atau sore hari? Apakah waktu kejadiannya berkaitan dengan waktu kejadian peristiwa di adegan lain, atau sudah lain hari? Pertanyaan-pertanyaan seputar waktu dan tempat kejadian ini akan memberikan gambaran peristiwa lakon yang lengkap.

\section{Tema}

Penulis menciptakan sebuah karya bukan hanya sekadar mencipta, tetapi juga menyampaikan suatu pesan tentang persoalan kehidupan manusia. Pesan itu bisa mengenai kehidupan lahiriah maupun batiniah. Pengarang 
adalah seorang warga masyarakat yang mempunyai pendapat tentang masalah-masalah politik dan sosial yang penting serta mengikuti isu-isu zamannya (Wellek dan Warren, 1990). Ide-ide, pesan atau pandangan terhadap persoalan yang ada dijadikan ide sentral atau tema dalam menulis karyanya. Tema ada yang menyebutnya sebagai premis, root idea, thought, aim, central idea, goal, driving force dan sebagainya. Seorang penulis cerpen terkadang mengemukakan tema dengan jelas, tetapi ada juga yang secara tersirat. Tema dapat diketahui dengan dua cara, yaitu apa yang diucapkan tokoh-tokohnya melalui dialogdialog yang disampaikan dan apa yang dilakukan tokoh-tokohnya.

\section{Nilai-nilai}

Makna nilai yang diacu dalam sastra menurut Waluyo (2002: 27) adalah kebaikan yang ada dalam makna karya sastra bagi kehidupan seseorang. Hal ini berarti bahwa dengan adanya pelbagai wawasan yang dikandung dalam karya sastra khususnya cerpen akan mengandung bermacam-macam nilai kehidupan yang bermanfaat bagi pembaca. Nilai-nilai dalam analisis ini dibedakan ke dalam dua kategori, yaitu aspek substansial dan aspek pragmatis. Secara substansial nilai-nilai berkaitan dengan kehidupan pribadi, kehidupan sosial, dan kehidupan religius. Sedangkan secara pragmatis nilai-nilai berfungsi untuk mendukung tujuan melangsungkan hidup, mempertahankan hidup, dan mengembangkan hidup.

\section{Teori Intertekstual}

Teori kajian intertekstual berasal dari Prancis dan bersumber pada aliran dalam strukturalisme Prancis yang dipengaruhi oleh pemikran filsuf Prancis, Jaquaes Derrida, kemudian dikembangkan oleh Julia Kristeva (Ratih 2003: 125). Teori Intertekstual memiliki asumsi bahwa sebuah teks sastra selalu terkait dengan teks-teks lain sebagai referensi maupun acuannya. Hubungan antarteks itu bisa kepada teks sastra lainnya, bisa juga berupa tiruan atas alam semesta (dalam pengertian yang lebih luas). Salah satu bentuk klasifikasi yang dilakukan dalam teori ini adalah seperti yang dilakukan Riffaterre yang memunculkan istilah teks hipogram untuk teks sebagai acuan bagi teks hasil transformasinya yang disebut teks transformatif.

\section{Prinsip intertekstualitas menyatakan} bahwa setiap teks sastra harus dibaca dengan latar belakang teks-teks lain; tidak ada suatu teks pun yang sungguh-sungguh mandiri. Penciptaan dan pembacaan sebuah teks tidak hanya meneladani teks lain dan mematuhi kerangkanya, tetapi mungkin juga terjadi berupa penyimpangan dan transformasi. Pemberontakan atau penyimpangan mengandaikan adanya sesuatu yang dapat diberontaki atau disimpangi; dan pemahaman teks baru memerlukan latar belakang pengetahuan tentang teks-teks yang mendahuluinya (Kristeva dalam Teeuw, 1994: 146).

Menurut Teeuw (1993: 62), kajian intertekstualitas dimaksudkan sebagai kajian terhadap sejumlah teks kesastraan, yang diduga mempunyai bentuk-bentuk hubungan tertentu, misalnya untuk menemukan adanya hubungan unsur-unsur intrinsik seperti ide, gagasan, 
peristiwa, plot, penokohan, gaya bahasa, da lainlain; di antara teks-teks yang dikaji. Secara lebih kritis dapat dikatakan bahwa kajian intertekstualitas berusaha menemukan aspekaspek tertentu yang telah ada pada karya-karya sebelumnya pada karya yang muncul lebih kemudian. Tujuan kajian interteks ini adalah untuk memberikan makna secara lebih penuh terhadap karya tersebut.

Masalah ada-tidaknya hubungan antarteks ada kaitannya dengan niatan pengarang dan tafsiran pembaca. Dalam kaitan ini, Luxemburg (1989: 10) mengartikan intertekstualitas sebagai: kita menulis dan membaca dalam suatu "interteks" suatu tradisi budaya, sosial, dan sastra, yang tertuang dalam teks-teks. Setiap teks sebagian bertumpu pada konvensi sastra dan bahasa dan dipengaruhi oleh teks-teks sebelumnya.

Karya sastra yang dijadikan dasar penulisan bagi karya yang kemudian oleh Riffaterre (1980: 23) disebut sebagai hipogram. Wujud hipogram mungkin bisa berupa penerusan konvensi, sesuatu yang lebih bereksistensi, penyimpangan dan pemberontakan konvensi, pemutarbalikan konvensi dan amanat teks sebelumnya. Dalam istilah lain, penerusan tradisi dapat disebut sebagai mitos pengukuhan (myth of concern), sedangkan penolakan tradisi disebut sebagai mitos pemberontakan (myth of freedom).

Unsur-unsur ambilan sebuah teks dari teks-teks hipogramnya mungkin berupa kata, sintagma, model bentuk, gagasan atau berbagai unsur intrinsik yang lain, namun dapat pula berupa sifat kontradiksinya, dapat menghasilkan sebuah karya yang baru sehingga karenanya mungkin orang tidak mengenali atau bahkan melupakan hipogramnya. Hipogram tidak harus lengkap, bisa saja hanya bersifat parsial, yang berwujud tanda-tanda teks atau pengaktualisasian unsur-unsur tertentu ke dalam bentuk-bentuk tertentu. Pengambilan bentuk-bentuk itu, atau derivasi bentuk-bentuk teks yang yang ditransformasikan itu, dapat hanya berupa varian leksikal, denotasi dan konotasi, pilihan paradigmatis kata-kata, atau pemakaian bentuk sinonim.

\section{METODOLOGI PENELITIAN}

\section{Metode Penelitian}

Metode yang digunakan dalam penelitian ini adalah metode deskriptif-analitis. Dalam penelitian ini data dikumpulkan, dideskripsikan, dianalisis, dan disimpulkan. Berdasarkan metode deskriptif-analitis tersebut, penelitian ini bertujuan untuk memberikan gambaran objektif mengenai (1) struktur dan nilai cerpen "Perempuan yang Ingin Membunuh Bisma" karya Ganug Nugroho Adi; (2) bentuk transformasi dari tokoh pewayangan Bisma ke dalam cerpen "Perempuan yang Ingin Membunuh Bisma" karya Ganug Nugroho Adi.

\section{Teknik Penelitian}

Teknik penelitian yang dilakukan untuk mendukung metode deskriptif ini, yaitu

(1) Studi dokumentasi

Studi dokumentasi ini berupa tulisantulisan yang berkenaan dengan tokoh Bisma dalam pewayangan dan transformasi tokoh Bisma dalam karya sastra.

(2) Analisis Data 
Analisis dilakukan terhadap karyakarya sastra yang menjadi sampel berdasarkan analisis struktur dan nilai sastra, selanjutnya dilakukan analisis transformasi dan analisis perbandingan. Teori analisis yang digunakan adalah teori Intertekstual.

Bagan Transformasi

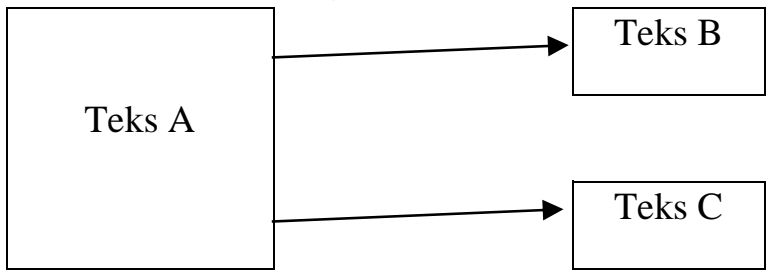

\section{Sumber Data}

Data penelitian ini adalah cerpen berbahasa Indonesia yang berjudul "Perempuan yang Ingin Membunuh Bisma" karya Ganug Nugroho Adi diambil dari Surat Kabar Harian Suara Merdeka tanggal 12 November 2007.

\section{PEMBAHASAN}

\section{Analisis Cerpen "Perempuan yang Ingin Membunuh Bisma"}

1. Sinopsis Cerpen "Perempuan yang Ingin Membunuh Bisma"

Bagian pertama dikisahkan tentang ayahanda Amba yang mengantarkan Amba dan dua saudaranya, Ambika dan Ambalika masuk ke dalam kereta untuk dibawa oleh Bisma karena telah memenangkan sayembara. Amba merasa sedih dan ingin memberontak, tetapi tidak kuasa. Ia merasa bahwa dirinya seharusnya tidak menjaidi bagian dari yang disayembarakan karena telah memiliki kekasih. Bahkan Amba telah bertunangan dengan kekasihnya yang bernama Salwa. Amba mengutuki Bisma yang telah memenangkan sayembara lalu dirinya berjanji untuk membalas dendam kepada Bisma.

Pada bagian kedua diceritakan mengenai situasi di Astina. Amba melakukan protes kepada Bisma. Akan tetapi, Bisma mengelak karena ayah Ambalah yang telah menyerahkan ketiga anaknya dan Amba harus patuh kepada titah orang tuanya. Amba bahkan menyesali karena Bisma sendiri tidak akan menikahinya. Akhirnya, Bisma mau menerima penjelasan Amba. Dia meminta maaf. Bisma kemudian berjanji akan mengantarkan Amba kepada Salwa pagi-pagi buta.

Pada bagian ketiga diceritakan mengenai pertemuan Amba dengan kekasihnya, Salwa di pendapa Saubala. Akan tetapi, Salwa memberikan reaksi yang tidak sesuai dengan harapannya. Dia menolak Amba karena dianggap sebagai barang buangan. Amba merasa sudah tidak ada tempat lagi baginya, akhirnya Amba memutuskan untuk menjadi pertapa agar memiliki kesaktian sehingga bisa membunuh Bisma.

Pada bagian keempat diceritakan tentang akhir pertempuran antara Kurawa dan Pandawa. Bisma dalam keadaan sekarat. Muncullah seorang perempuan berkelebat mendekat, yaitu Amba. Tak ada yang bisa melihat perempuan yang tetap jelita ini kecuali Bisma. Para Kurawa dan Pandawa seperti tak terusik dengan kedatangan Amba, dan terus meratapi Bisma. Amba merasa telah lunas menunaikan dendamnya kepada Bisma dengan menitis pada tubuh Srikandi.

2. Alur Cerpen "Perempuan yang Ingin Membunuh Bisma"

Seperti halnya cerita pendek yang ruang untuk berkisah sangat terbatas, cerpen ini pun hanya mengambil empat episode kisah Bisma, yaitu (1) kepergian Amba bersama 
ketiga adiknya ke Astina; (2) percakapan Amba dengan Bisma mengenai permintaanya untuk dikembalikan; (3) penolakan Salwa, kekasih Amba, karena telah dianggap sebagai barang rongsokan; (4) akhir pertempuran Kurawa dan Pandawa yang ditandai dengan meninggalnya Bisma.

Keempat episode ini lebih tampak sebagai seting untuk mewadahi pikiranpikiran tokoh Amba sehingga lebih banyak berisikan mengenai percakapan-percakapan, baik dengan tokoh lain, maupun dengan dirinya sendiri. Cerita juga lebih banyak berisi deskripsi pengarang mengenai latar suasana untuk memperkuat pikiran dan perasaan tokoh Amba. Untuk memahami alur seperti ini yang mengambil episode-episode tertentu diperlukan wawasan yang utuh mengenai kisah Bisma dalam cerita pewayangan.

\section{Penokohan Cerpen "Perempuan yang Ingin} Membunuh Bisma"

Dari judulnya, "Perempuan yang Ingin Membunuh Bisma", dapat diduga bahwa tokoh yang diangkat dalam kisah Bisma ini adalah tokoh Amba. Bahkan pengedepanan tokoh Amba ini diperkuat oleh pengarang dengan mengambil sudut pandang "akuan", seperti pada kutipan berikut,

Saya merasakan roda kereta seperti menggerus dada, memerih hingga ke tulang, mencabik-cabik hati saya, menjadi layaknya debu yang berhamburan di sisi kanan-kiri kereta yang melaju kencang.

Tokoh Amba digambarkan sebagai perempuan yang berkarakter kuat. Ia mengutuki nasib yang menimpanya. Ia harus meninggalkan kekasihnya gara-gara orang tuanya membuat sayembara. Ia ingin melawan orang tuanya, tetapi sebagai seorang anak dan juga perempuan, dirinya tidak memiliki kekuasaan.

Saya menahan marah yang menggumpal. Tapi saya tak ingin menangis. Mereka yang sedang tak jatuh cinta memang selalu menganggap remeh arti sebuah percintaan. Sebagai anak raja, apalagi perempuan, kau tak boleh membangkang apa yang menjadi keinginan raja.

Kekuatan karakter Amba terlihat pula pada episode kedua, dirinya berusaha membujuk Bisma dan mengajukan argumen sehingga Bisma mengalah untuk mengembalikan Amba kepada kekasihnya. Karena kekasihnya tidak mau menerima lagi, Amba memutuskan untuk bertapa dan berjanji akan membalas Bisma.

Kau tahu, Bisma, betapa aku ingin menjelma srigala yang tega mencabikcabik tubuhmu. Ingin aku beralih rupa menjadi ribuan anak panah yang meluncur deras dan menembus tubuhmu, membuat daging dan kulitmu serupa serpihan-serpihan hingga tak sedebu pun darimu tersisa. Aku ingin membunuhmu!

Tokoh lainnya yang menjadi pemeran penting dalam cerpen ini adalah Bisma. Tokoh inilah yang menjadi motif dalam menggerakkan semua cerita. Tokoh Bisma ini digambarkan sebagai orang yang memiliki kesaktian luar biasa. Dia bisa memenangi sayembara sehingga dapat memboyong tiga orang putri Kerajaan Kasi. Tokoh ini digambarkan pula sebagai orang yang memiliki kepedulian dan kasih sayang. Dia mencarikan calon istri untuk kedua adik tirinya. Dia juga terbukti dapat luluh oleh bujuk rayu Amba. Bisma juga memutuskan 
untuk tidak melawan perempuan. Dia akhirnya dikalahkan oleh Srikandi.

Tokoh-tokoh lain yang namanya muncul dalam cerpen ini, tetapi tidak memiliki peran utama adalah Darmahumbara (ayah Amba), Ambika dan Ambalika (adik Amba), Salwa (kekasih Amba), Wicitrawirya (adik Bisma), dan Srikandi. Nama-nama tersebut muncul semata-mata hanya sebagai nama yang tak terhindarkan untuk disebut dalam cerpen.

4. Seting Cerpen "Perempuan yang Ingin Membunuh Bisma"

Sebagaimana cerita yang diambil dari kisah pewayangan, seting cerpen ini adalah kerajaan di dunia pewayangan. Episode pertama menceritakan kepergian Amba dan kedua adiknya dari tempat asalnya, yaitu Kerajaan Kasi. Dalam cerpen ini tidak disebutkan nama kerajaannya, tetapi nama kerajaan yang ditujunya disebutkan, "Kereta bergerak, membawa saya dan adik-adik saya menuju Astina”. Demikian juga pada episode kedua Kerajaan Astina disebut kembali, "Pada malam sesampai di Astina saya langsung menemui Bisma".

Peristiwa yang terjadi pada episode ketiga adalah di tempat kediaman Salwa, kekasih Amba, yaitu pendapa Saubala. Pada saat itu Amba bermaksud kembali ke pelukan Salwa, tetapi Salwa menolak untuk menerima kembali dirinya. "Siang itu saya bertemu Kangmas Salwa di pendapa Saubala. Hati saya sangat bergelora menyampaikan bahwa saya telah bebas dari Bisma dan ingin segera menikah dengannya".

Sedangkan seting yang dalam episode terakhir adalah padang Kurusetra, tempat bertempurnya Kurawa dan Pandawa. Di tempat ini pula Bisma gugur,

Sisa debu pertempuran masih

beterbangan pada hari terakhir perang besar Baratayuda itu. Menjelang senja, para Kurawa dan Pandawa menepi. Di depan mereka, di bawah pohon besar Kurusetra, Bisma baru saja ambruk. Semua membisu. Semua tertunduk. Semua diam dengan dada tetap bergemuruh.

5. Tema Cerpen "Perempuan yang Ingin Membunuh Bisma"

Berdasarkan informasi hasil analisis terhadap alur, penokohan, dan seting cerpen "Perempuan yang Ingin Membunuh Bisma" ini bertemakan perjuangan seorang wanita untuk mendapatkan harkat martabatnya. Penulis cerpen menempatkan tokoh utama Amba menunjukkan bahwa cerita ini tentang kiprah seorang perempuan. Amba berusaha untuk protes kepada ayahnya, walaupun sebatas dalam hatinya. Amba juga melakukan protes kepada Bisma, kemudian ia melakukan perlawanan kepada Bisma karena telah menjadikan dirinya terkatung-katung.

6. Nilai-nilai dalam Cerpen "Perempuan yang Ingin Membunuh Bisma"

Nilai-nilai yang paling tampak dalam cerpen ini sejalan dengan tema cerpen berkaitan dengan harkat martabat seorang perempuan atau secara substansial berkaitan dengan masalah kehidupan sosial. Pandangan feminisme yang sering menjadi sorotan pada satu dekade terakhir ini sangat mewarnai cerpen ini. Karya sastra sering dijadikan sebagai media untuk membongkar ideologi dan sekaligus menanamkan ideologi lain. Demikian pula dengan cerpen ini yang memuat dengan gamblang nilai-nilai ideologis feminis.

Pada paragraf pertama, kata-kata yang dilontarkan oleh ayah Amba menunjukkan pola subordinat seorang anak terhadap orang tuanya, apalagi anak perempuan, “....Lupakan Salwa. Sebagai perempuan, kau tak punya pilihan". 
Posisi seorang perempuan seperti itu diungkapkan pada bagian lain, bahkan dengan jelas pengarang menggunakan tokoh Amba ini untuk mempertanyakan perlakuan seorang laki-laki terhadap perempuan,

Menyadari saya adalah seorang perempuan yang tak memiliki kuasa apa-apa bahkan atas tubuh dan keinginan saya sendiri membuat hati saya perih. Padahal saya anak raja. Padahal saya bukan perempuan kebanyakan. Apakah akan selalu demikian nasib para perempuan?

Kata-kata yang mirip dengan ucapan ayah Amba, dikatakan pula oleh Bisma, "Ayahmu sendiri yang menyerahkan dirimu dan adikadikmu setelah sayembara itu. Seorang anak raja tidak seharusnya membantah perintah rajanya. Apalagi kau hanya seorang perempuan".

Cerita yang mengambil sudut pandang tokoh Amba ini menjadi jalan bagi penulisnya untuk mengungkapkan ketidakadilan gender karena cerita ini mengisahkan perempuan yang dijadikan sebagai objek sayembara. Tokoh Amba ini oleh penulisnya dijadikan sebagai representasi perempuan yang mampu melawan subordinasi kaum lelaki. Tokoh Amba adalah tokoh perempuan yang berani melawan ketidakadilan gender. Dia bahkan mengkritik tokoh Srikandi yang disebutnya sebagai banci yang walaupun berani berperang, tetapi tetap sebagai perempuan yang tidak berani melawan ketidakadilan gender.

\section{Transformasi Tokoh Bisma dalam Cerpen "Perempuan yang Ingin Membunuh Bisma"}

Berdasar pada kisah pewayangan Bisma, transformasi secara utuh terjadi pada alur cerpen "Perempuan yang Ingin
Membunuh Bisma". Cerpen ini menggunakan alur linier atau alur maju. Tidak ada alur peristiwa yang menyimpang dari hipogramnya. Walaupun demikian, sebagai sebuah cerpen yang serba terbatas, membaca cerpen "Perempuan yang Ingin Membunuh Bisma" ini baru akan dipahami jika pengetahuan pembaca dimulai dari latar belakang keluarga Bisma yang masa mudanya dikenal sebagai Dewabrata.

Demikian pula dengan nama-nama tokoh yang muncul dalam cerpen ini sama persis dengan nama-nama dalam kisah pewayangan tentang kehidupan Bisma, seperti Amba, Ambika, Ambalika, Salwa, dan Wicitawirya. Sedangkan pada nama-nama tempat selain terdapat beberapa penyebutan nama tempat yang sama, terdapat juga penamaan yang sedikit berbeda, misalnya dalam hipogramnya menggunakan nama Hastina, dalam cerpen disebut Astina.

Yang membedakan cerpen "Perempuan yang Ingin Membunuh Bisma" dengan hipogramnya adalah penguatan pada unsur tema dan pemuatan nilai-nilai ideologis feminisme. Penulis dengan sengaja menempatkan tokoh Amba yang bergender perempuan sebagai tokoh sentral. Penulis tampak dengan sengaja bingkai peristiwa kisah Bisma karena memiliki celah yang kuat untuk memasukkan nilai-nilai ideologi feminisme. Celah-celah itu di antaranya adalah peristiwa sayembara yang menjadikan kaum perempuan sebagai objek yang dengan mudah dipertaruhkan. Celah-celah lainnya adalah perlawanan Amba yang menitis pada tokoh Srikandi mampu mengalahkan Bisma, seorang lelaki yang memiliki kekuatan luar biasa. Hal ini juga menjadi simbol bahwa sekuat-kuatnya laki-laki akhirnya takluk juga di hadapan wanita.

Fakultas Keguruan dan Ilmu Pendidikan 
Bagan Transformasi Kisah Bisma dalam Cerpen "Perempuan yang Ingin Membunuh Bisma"

\begin{tabular}{|c|c|c|}
\hline \multirow{5}{*}{$\begin{array}{c}\text { Teks } \\
\text { Hipogram }\end{array}$} & Alur & $\begin{array}{l}\text { Sama dengan } \\
\text { hipogram } \\
\text { mengambil } \\
\text { sebagian } \\
\text { peristiwa }\end{array}$ \\
\hline & Tokoh & $\begin{array}{l}\text { Sama dengan } \\
\text { hipogram - } \\
\text { mengambil } \\
\text { tokoh utamanya } \\
\text { saja }\end{array}$ \\
\hline & Seting & $\begin{array}{l}\text { Sama dengan } \\
\text { hipogram } \\
\text { mengambil } \\
\text { sebagian tempat } \\
\text { kejadian }\end{array}$ \\
\hline & Tema & $\begin{array}{l}\text { Terdapat } \\
\text { penguatan pada } \\
\text { tema, yaitu } \\
\text { tentang harkat } \\
\text { martabat } \\
\text { perempuan }\end{array}$ \\
\hline & $\begin{array}{l}\text { Nilai- } \\
\text { nilai }\end{array}$ & $\begin{array}{l}\text { Terdapat } \\
\text { tambahan } \\
\text { muatan nilai- } \\
\text { nilai ideologis } \\
\text { feminisme, } \\
\text { kritik terhadap } \\
\text { ketimpangan } \\
\text { gender. }\end{array}$ \\
\hline
\end{tabular}

Transformasi yang terjadi pada cerpen "Perempuan yang Ingin Membunuh Bisma" merupakan bentuk intertekstual yang eksplisit. Cerpen ini mengambil pola yang sesuai dengan hipogramnya, baik alur, tokoh maupun seting. Walaupun demikian, pengarang telah menggunakan kebebasan dan kreativitasnya dalam membentuk kisah tentang Bisma.
Dalam cerpen ini, pengarang tampak memanfaatkan celah-celah untuk memasukkan ide-idenya. Pada cerpen "Perempuan yang Ingin Membunuh Bisma" pengarang memanfaatkan celah-celah kisah Bisma ini untuk memasukkan ideologi feminisme. Pengarang ingin menyadarkan pembaca mengenai ketidakadilan gender dan ingin menempatkan kaum perempuan setara dengan kaum laki-laki. Celah-celah yang digunakan oleh pengarang dimanfaatkan dengan baik sehingga transformasi dalam cerpen ini tampak utuh. Unsur tambahan berupa ideologi feminisme dibangun menjadi satu kesatuan yang kohesif dalam keseluruhan cerita.

Dari cerpen di atas tampak bahwa cerita pewayangan dijadikan sebagai teks asal (hipogram) untuk menyusun teks baru, dalam hal ini cerita pendek dengan berbagai macam gaya dan variasinya sesuai dengan kreativitas pengarang. Dalam cerpen ini tidak ada perbedaan dalam mentransformasikan alur dan penokohan dari teks asalnya.

\section{SIMPULAN}

Dari hasil analisis dan pembahasan terhadap cerpen "Perempuan yang Ingin Membunuh Bisma" dapat disimpulkan hal-hal berikut.

1) Terdapat kesamaan struktur antara teks asal dengan cerpen "Perempuan yang Ingin Membunuh Bisma”. Alur cerita, tokoh, dan seting cerita mengambil dari teks asalnya tentang tokoh Bisma. Walaupun demikian, untuk dapat memahami secara utuh pembaca haruslah mengetahui latar belakang cerita kehidupan Bisma ketika muda dengan nama Dewabrata.

2) Nilai-nilai yang terdapat dalam cerpen "Perempuan yang Ingin Membunuh Bisma" karya Ganug Nugroho Adi berkaitan dengan transformasi dari 
hipogramnya adalah nilai-nilai ideologi feminisme yang mewarnai seluruh cerita karena mengambil sudut pandang penceritaan dari tokoh Amba. Tokoh Amba sebagai representasi perempuan yang disubordinasi oleh kaum lelaki, baik oleh ayahnya sendiri, maupun oleh Bisma.

\section{DAFTAR PUSTAKA}

Clement, Robert J. 1978. Comparative Literature as Academic Discipline. New York: The Modern Language of America.

Culler, Jonathan. 1977. Structuralist Poetics. London: Metguen \& Co. Ltd.Endraswara, Suwardi. 2011a. Metodologi Penelitian Sastra Bandingan. Jakarta: Caps.

Endraswara, Suwardi. 2011b. Sastra Bandingan: Pendekatan dan Teori Pengkajian. Yogyakarta: Lumbung Ilmu.

Jabrohim (ed). 2003. Metodologi Penelitian Sastra. Yogjakarta: Hanindita.

Luxemburg, Jan van, dkk. 1989. Pengantar Ilmu Sastra. Jakarta: Gramedia.
Nurgiyantoro, Burhan. 1998. Transformasi Unsur Pewayangan dalam Fiksi Indonesia. Yogyakarta: Gadjah Mada University Press.

Nurgiyantoro, Burhan. 2010. Teori Pengkajian Fiksi. Yogjakarta: Gajah Mada University Press.

Ratih, Rina. 2003. "Pendekatan Intertekstual Dalam Karya Sastra" dalam Metodologi Penelitian Sastra. Jabrohim (ed.). Yogyakarta: Hanindita Graha Widya.

Riffatere, Michael. 1980. Semiotics of Poetry. Bloomington: Indiana University Press.

Sudjiman, Panuti. 1984. Memahami Cerita Rekaan. Jakarta: Pustaka Jaya

Teeuw, A. 1993. Membaca dan Menilai Sastra. Jakarta: Gramedia.

Teeuw, A. 1994. Sastra dan Ilmu Sastra, Pengantar Teori Sastra. Jakarta: Pustaka Jaya.

Waluyo, Herman J. 2002. Teori dan Apresiasi Puisi. Jakarta: Erlangga.

Wellek, Rene dan Austin Warren. 1989. Teori Kesusastraan. Terjemahan Melani Budianta. Jakarta: Gramedia. 